Article

\title{
Research and Application of New Technology of Bionic Enhanced Wellbore and Strong Lubrication Water-Based Drilling Fluid
}

\author{
Xiaohu Quan ${ }^{1,2}$, Guancheng Jiang ${ }^{1,2, *}$, Xuwu Luo ${ }^{1,2,3}$, Yinbo He ${ }^{1,2}$ and Tengfei Dong ${ }^{1,2}$ \\ 1 State Key Laboratory of Petroleum Resources and Prospecting, China University of Petroleum (Beijing), \\ Beijing 102249, China; dzhq1210@163.com (X.Q.); lxw2312@cnpc.com (X.L.); HYB123@163.com (Y.H.); \\ dtf221@163.com (T.D.) \\ 2 College of Petroleum Engineering, China University of Petroleum (Beijing), Beijing 102249, China \\ 3 Drilling Fluid Branch of CNPC Western Drilling Company, Karamay 834009, China \\ * Correspondence: jgc5786@126.com; Tel.: +86-010-89732196
}

Received: 10 September 2020; Accepted: 9 October 2020; Published: 12 October 2020

\begin{abstract}
After more than a century of development, drilling fluid technology has become capable of dealing with various extreme conditions. As the exploration and development targets shift towards complex oil and gas resources, however, the geological and surface conditions encountered get increasingly complex, which poses a greater challenge to drilling fluid. In this paper, bionics is introduced into the field of drilling fluids, imitating the characteristics, functions, structures, and principles of mussels and earthworms, and a bionic wall-fixing agent with side chains containing catechol functional groups to strengthen the wellbore is prepared. A bionic bonding lubricant that when making the direct friction between the two is changed to the sliding between the membranes is prepared. Compared with the advanced technology introduced from abroad, the strength of the rock is not only reduced but increased by more than $14 \%$, the friction reduction rate is improved by $12.3 \%$. Their mechanism of action and influencing factors are revealed from the macro and micro perspectives. Combined with the formation conditions encountered, other treatment agents are applied to develop a novel technology of bionic strengthened borehole and high lubricity water-based drilling fluid with comparable inhibition and lubricity to oil-based drilling fluid. In comparison with technology, the rate of well collapse is reduced by as much as $82.6 \%$, the accident rate of stuck pipe is brought down by as much as $86.4 \%$, the complication of stuck block is reduced by as much as $79.7 \%$, and the overall cost is lowered by more than $30 \%$. It is truly a safe, efficient, economic, environmentally friendly drilling fluid technology.
\end{abstract}

Keywords: bionics; drilling fluid; bionic drilling fluid treatment agent; bionic drilling fluid

\section{Introduction}

Drilling fluid, which is the blood of drilling engineering, is a complex multilevel dispersion fluid. Since the application of clear water natural pulping as drilling fluid during the period from 1904 to 1921, it has successively experienced the start-development-improvement-redevelopment stage [1-6]. Over more than a century of relentless development, over 100 varieties of drilling fluid systems have been developed, which has played a critical role in reducing drilling complications, exploring reservoirs, boosting yield, preventing complicated downhole conditions or accidents, and dealing with various extreme conditions. However, most of the oil and gas resources newly discovered in China and around the world are low permeability, unconventional, deep water, deep layers, and other difficult-to-use oil and gas resources, and are concentrated in mountainous areas, deserts, plateaus, loess plateaus, the Arctic Circle, and ocean-covered areas [7-10]. Currently, geological and surface 
conditions are becoming more and more complex, which means exploration and development are made increasingly difficult. Due to such complex underground and surface conditions as well collapse, stuck pipe, environmental pollution related to drilling fluids or frequent occurrence of accidents, high costs and high efficiency and the low level, drilling fluid technology is faced with unprecedented challenges [11-13].

In general, oil-based drilling fluid is considered the top choice for drilling difficult wells due to its excellent wall stability and lubricity. In spite of this, it shows drawbacks such as severe environmental damage, high preparation costs, the difficulty in spillage treatment, and poor cementing quality [14-16]. Due to the stringent requirements for environmental preservation and significant fluctuations in oil prices, research has been conducted both at home and abroad on the high-performance water-based drilling fluids with the advantages of water-based and oil-based drilling fluids, despite no breakthroughs having been made over the past decade. Therefore, it is necessary to introduce the advanced basic theoretical knowledge in other disciplines, pursue theoretical method innovation and key technological breakthroughs, create new drilling fluid theories and technologies, and achieve the goals of safe, efficient, economical, and environmental protection exploration and development.

Nature provides an inexhaustible source of various technical ideas and inventions. Since ancient times, bionic activities have always accompanied humanity, and many major inventions that have affected the progress of human civilization have benefited from bionics. The first bionics symposium held in the United States in 1960 marked the emergence of bionics as an independent discipline. The bionic technology developed using bionics has the technical superiority that cannot be solved by conventional technical means, and has the advantages of originality and being forward-looking, occupying the commanding heights of high and new technology [17-24].

Based on the consideration stated above, this paper aims to:

(1) Introduce bionics into the field of drilling fluids, and uses the functions, principles, and structures of marine mussels and earthworms as learning models to address the inherent defects of wellbore stability and lubricity in water-based drilling fluids.

(2) Develop biomimetic wall-fixing agents and biomimetic bonding lubricants, and reveal their mechanism of action to achieve 'borehole strengthening and strong lubrication', and establish new technologies for bionic strengthened boreholes and strong lubricating water-based drilling fluids, through indoor system evaluation and on-site. According to the results of large-scale promotion and application, the inhibition and lubricity of water-based drilling fluids are comparable to oil-based drilling fluids, thus providing technical support for safe, efficient, economical, and environmentally friendly drilling in difficult wells under exceptional and complex formation conditions.

\section{Materials and Methods}

\subsection{Apparatus}

Point testing is conducted in YSD-2 rock uniaxial compressive strength testing machine (Tianjin Meites testing machine factory); Linear expansion experiment is conducted in two channel intelligent linear expansion meter (Kendall instruments (Shanghai) Co., Ltd); Contact angle testing is conducted in JC2000DM series contact angle measuring instrument (Beijing Zhongyi Kexin Technology Co., Ltd); Lubricant performance testing is conducted in Fann212 extreme pressure lubricator; Quanta 200F field emission environmental scanning electron microscope; T100 multifunctional friction and wear tester; ZNN-D6 digital display six speed rotational viscometer, roller heating furnace, SD6-SD6B six link medium pressure filtration meter, GGS71-A high temperature and high pressure filtration meter are purchased from Sidilaibo.

\subsection{Developing of Bionic Wall-Fixing Agent}

Wellbore instability has long been causing trouble in the safety and efficiency of drilling [25-30]. In some extreme cases, it can result in drilling failure. People have established a series of mechanical, 
chemical, mechanical-chemical coupling, and multi-coupling wellbore stabilization drilling fluid technologies after decades of research work, and have achieved good results, but they cannot improve the wellbore rock cohesion. The strength and rock cementing power, the inability to suppress surface hydration, and the difficulty in plugging nano-scale pores, etc., making the effect of stabilizing the wellbore limited and far from the oil-based drilling fluid's ability to stabilize the wellbore.

\subsection{Research and Development of Bionic Wall-Fixing Agent}

Marine mussel organisms cement rocks by secreting high-strength, high-toughness, extremely strong adhesion, and waterproof adhesion proteins [31-36]. The main component of adhesion proteins, dopa, demonstrates good biocompatibility and degradability, and its molecular structure contains a large number of catechol groups with chemical versatility and affinity diversity. It can adhere to the base surface tightly through conformational changes, cross-linking between chains, and electrostatic and chemical interactions with the substrate. A microscopic biological network serves to increase the adhesion and cohesion of mussel adhesion protein.

Inspired by this, acrylic acid was first grafted onto polyvinyl alcohol. Then, with - $\mathrm{COOH}$ and $-\mathrm{NH}_{2}$ in the adhesion functional element as the reactive functional groups, through the acylation reaction, the adhesion of the catechol group-containing monomer occurred. The body was grafted onto part of the polyacrylic acid on the side chain of polyvinyl alcohol to obtain catechol-containing functional groups on the side chain. It can chelate and crosslink with $\mathrm{Fe} 3+$ ions and divalent metal ions such as $\mathrm{Ca} 2+$ and $\mathrm{Mg}^{2+}$ in the rock of the well wall. A microbial bionet was developed on the rock of the well wall. By solidifying the well wall, it can improve the adhesion and cohesion of the rock wall. The preparation process is illustrated in Figure 1.
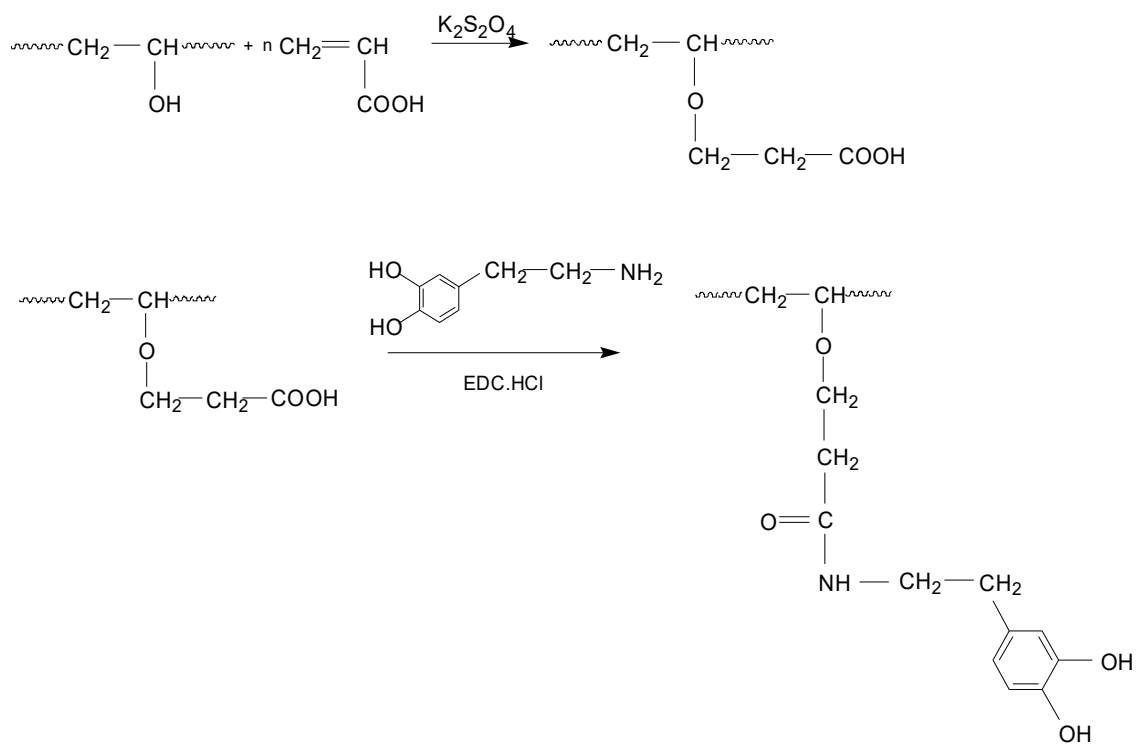

Figure 1. Synthetic steps of bionic wall-fixing agent.

\subsection{Mechanism of Action of Bionic Wall-Fixing Agent}

The bentonite was dried at $105{ }^{\circ} \mathrm{C}$ for $4 \mathrm{~h}$, cooled to room temperature, and placed in a dryer for standby. A sample of 5-10 g was weighed with a balance and loaded into the die. The die was patted by hand to make the end face of the sample flat, and a piece of filter paper was placed on the surface. The pressure bar was placed in the mold, the combined sample was placed on the hydraulic press platform, pressurized for $4 \mathrm{MPa}$, and the pressure was released after $5 \mathrm{~min}$ to obtain the man-made mudstone core.

The same man-made mudstone core was immersed in deionized water and $0.5 \%$ bionic fixative solution for different periods of time, as shown in Figure 2. It can be seen from Figure 2 that the core 
completely collapsed after being immersed in deionized water for $10 \mathrm{~min}$. By contrast, it remained well after being immersed in $0.5 \%$ bionic wall-fixing agent solution for $30 \mathrm{~h}$, with a thin layer of gel film similar to the biological net observed on the surface. The beaker shown in the left of each picture contained deionized water, while the beaker on the right contained a $0.5 \%$ bionic fixative solution.

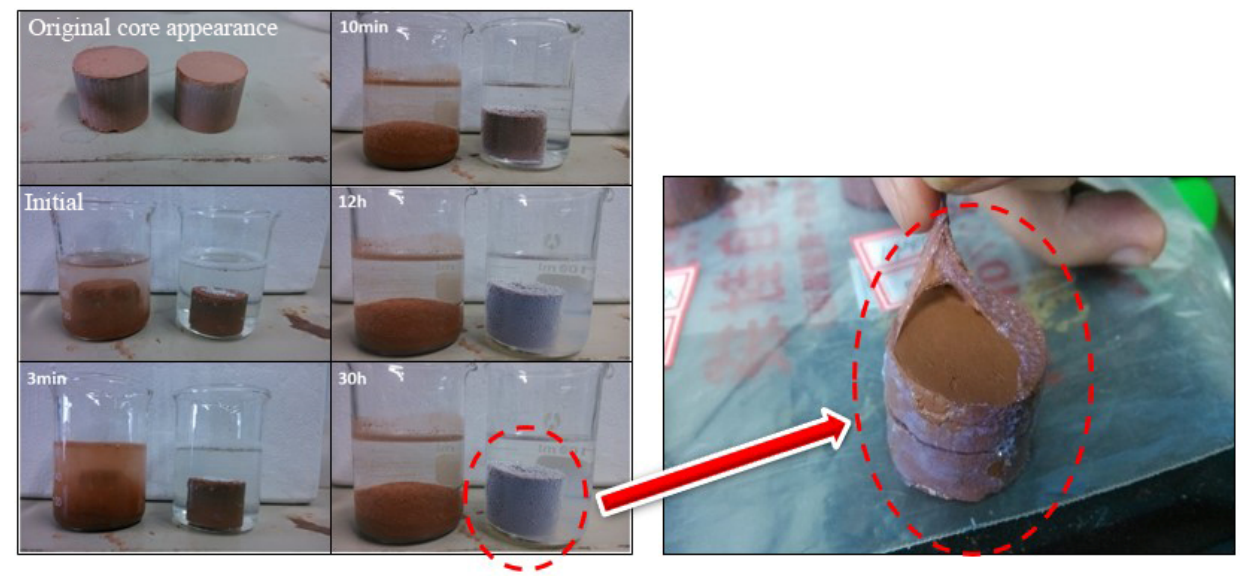

Figure 2. Morphological changes of mudstone core immersed in deionized water and bionic wall-fixing agent solution at different times.

As revealed by X-ray fluorescence spectroscopy analysis of the mudstone core (Table 1), in addition to $\mathrm{Al}$ and $\mathrm{Si}$ as two main elements, the mudstone also contains a small amount of such elements as $\mathrm{Na}$, $\mathrm{Mg}, \mathrm{Ca}$, and Fe. From the results (Figure 3) of energy dispersive X-ray spectroscopy (EDS) spectrum analysis of the biomimetic cementing agent forming a gel film on the surface of mudstone, however, it was found out that in addition to the elements $\mathrm{C}$ and $\mathrm{O}$ (bionic cementing agent contained), the gel film also contains biomimetic solids $\mathrm{Ca}$ and $\mathrm{Mg}$ which are not present in the wall solution, and that the concentration of $\mathrm{Ca}$ is significantly higher than in the original mudstone, suggesting that the gel film on the surface of mudstone results from chelating and crosslinking reaction between the bionic wall-fixing agent and $\mathrm{Ca}^{2+}$ and $\mathrm{Mg}^{2+}$. In the meantime, when the chelating and crosslinking reaction occurs, $\mathrm{Ca}^{2+}$ migrates from the interior of the mudstone to the surface on a continuous basis. Thus, the mechanism of action of the biomimetic wall-fixing agent is that when the solution of the biomimetic wall-fixing agent invades the pores of the mudstone, the exchangeable cations (such as $\mathrm{Ca}^{2+}, \mathrm{Mg}^{2+}$, etc.) inside the mudstone are continuously replaced with the ionized $\mathrm{H}+$ of the biomimetic wall-fixing agent, thus leading to the concentration of mud shale on the surface. Then, the functional groups contained in the bionic wall-solidifying agent are adsorbed onto the surface of the mudstone chelate and crosslink with the surface-concentrated $\mathrm{Ca}^{2+}, \mathrm{Mg}^{2+}$ plasma to generate a bio-like gel film, thus improving the adhesion of the mudstone core force and cohesion, which is beneficial not only for preventing water molecules from intruding into the mudstone, but also to improve the strength of cement shale bonding and the stability of the shaft wall. This is consistent with the mechanism of marine mussel secretions cementing rocks.

Table 1. X-ray fluorescence spectrum analysis results of mudstone.

\begin{tabular}{cc}
\hline Element & Content/\% \\
\hline $\mathrm{Al}$ & 17.87 \\
$\mathrm{Si}$ & 55.50 \\
$\mathrm{Na}$ & 1.32 \\
$\mathrm{Mg}$ & 3.70 \\
$\mathrm{Ca}$ & 9.78 \\
$\mathrm{Fe}$ & 7.02 \\
Others & 4.81 \\
\hline
\end{tabular}




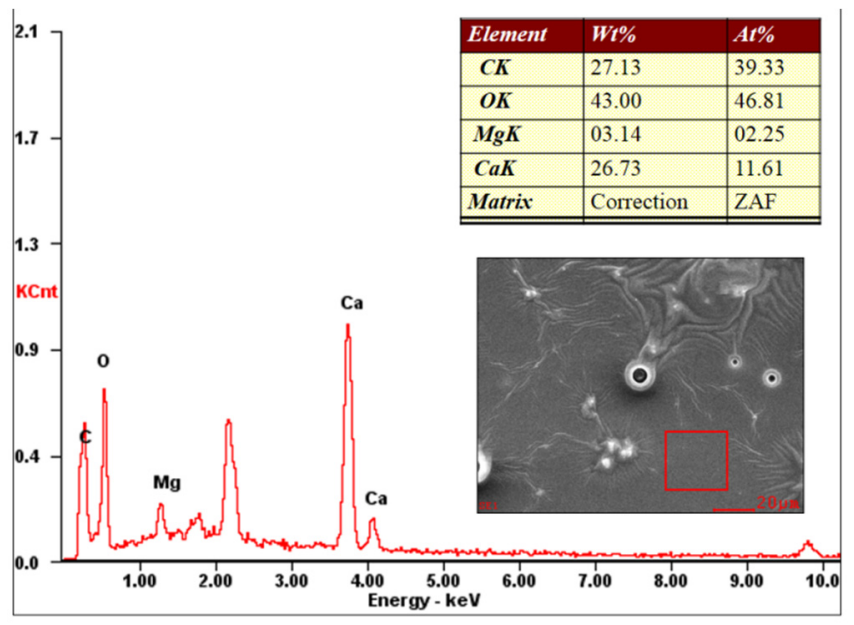

Figure 3. EDS spectrum analysis result of gel film formed on the surface of mudstone by bionic wall-fixing agent.

\section{Results}

\subsection{Performance Evaluation of Bionic Wall-Fixing Agent}

\subsubsection{Fixing Wall Performance}

Since the bionic gel film generated by the bionic wall-fixing agent on the rock surface of the well wall can produce the effect of cementing the rock, qualitative and quantitative evaluations were conducted separately to assess its effectiveness in improving the strength of the rock.

\section{Qualitative Evaluation of Soaking Experiment}

A $2 \%$ solution containing different treatment agents was prepared for the core immersion experiment at room temperature and atmospheric pressure. As shown in Figure 4, the morphology of the mudstone core in each solution changes over time. It can be seen from Figure 4 that the mudstone core remained intact and showed no visible cracks after $72 \mathrm{~h}$ of immersion in the bionic wall-fixing agent solution, while the cores immersed in other solutions cracked and collapsed to varying degrees after around $24 \mathrm{~h}$, which happened because the bionic wall-fixing agent bound onto the rock surface and inside. As a result, the bonding ability between the core particles improved, and the ingress of free water into the core was hindered. The result was also better than that reported in previous literatures $[37,38]$.
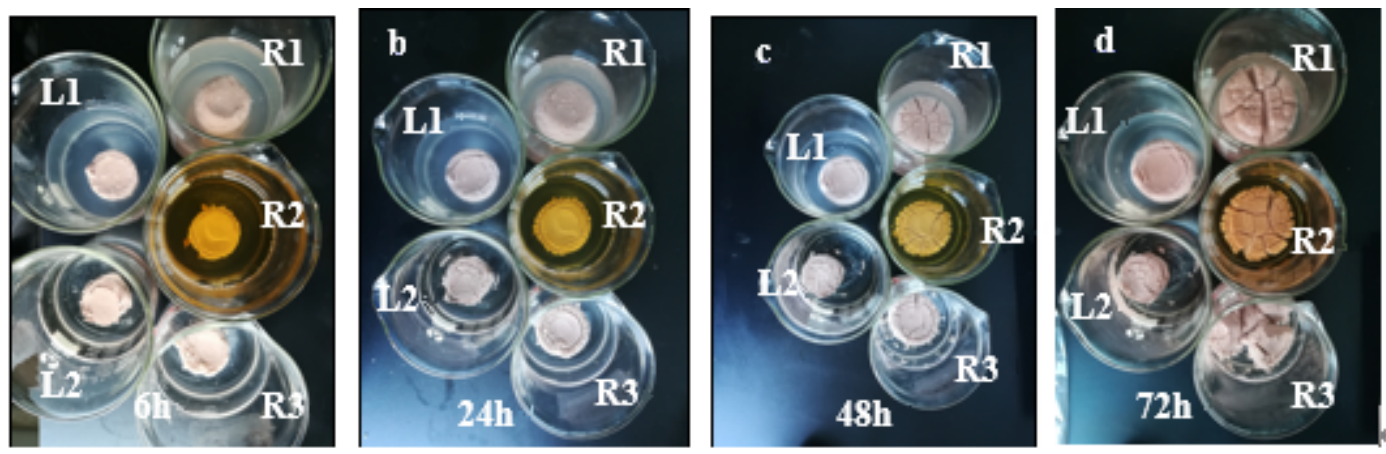

Figure 4. Variation of mudstone core shape with time in distilled water (R1), 2\% polyalcohol (R2), 2\% polyetheramine (R3) and 2\% bionic wall-fixing agent (GBFS-1) solution (L1), 2\% poly diallyl dimethyl ammonium chloride (DMDAAC) (L2) solution. 
After the mudstone cuttings were immersed in clear water and $2 \%$ bionic wall-fixing agent solution for $1 \mathrm{~h}$, the large parts were completely hydrated and dispersed in the clear water to obtain a red mud. Not only did dispersion occur in the bionic wall-fixing agent solution, the gel is also bound more tightly, as shown in Figure 5.
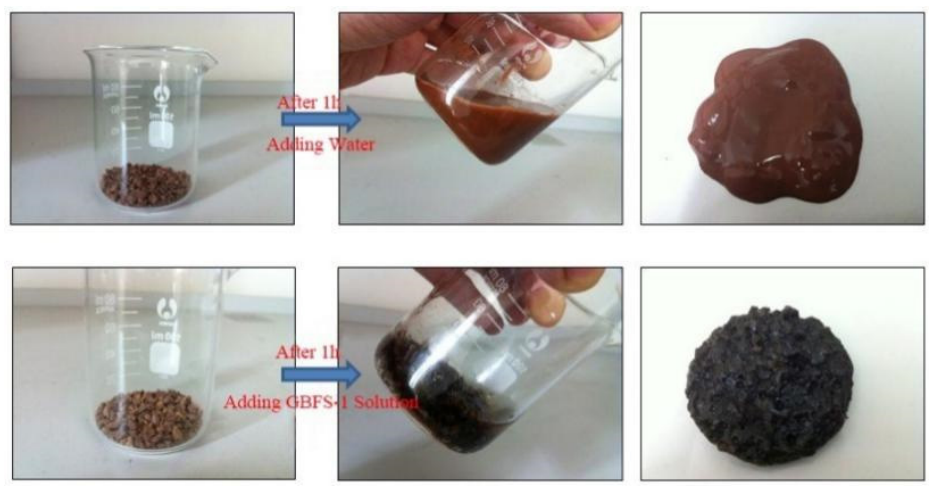

Figure 5. Changes in morphology of mudstone cuttings immersed in fresh water and $2 \%$ bionic fixative solution.

\section{Quantitative Evaluation}

\section{(1) Point load test}

Point load test is a method to test the compressive strength of rock under point load. During the test, the specimen is clamped between two spherical loading cones, and the load is applied until the fracture sample is fractured. According to the maximum load at failure and the distance between the ends of two cone heads, the tensile strength of the specimen can be calculated, and the compressive strength of the specimen can be calculated.

According to the data shown in Figure 6, the force of the core after immersion in clear water deteriorated significantly was up to as low as $0.08 \mathrm{~N}$, indicating a severe hydration of the core. The force was improved to $0.2 \mathrm{~N}$, with the effect being clearly better than that of the other three treatment agents after soaking.

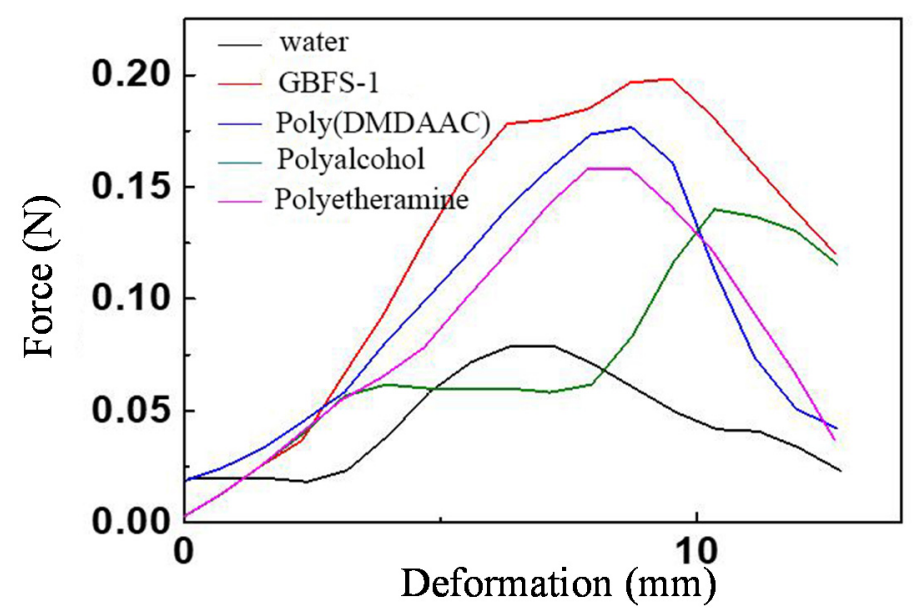

Figure 6. Force-deformation curve of point load test.

(2) Core breaking strength

The core uniaxial stress experiment was used to test the breaking strength of core. The uniaxial compressive strength of rock is called uniaxial compressive strength when the rock sample is 
subjected to compression failure under the action of longitudinal pressure under the condition of unconfined pressure.

Upon a uniaxial stress test of the core, the rock strengthening ability of the bionic wall-fixing agent to the core was assessed, as shown in Table 2, which indicates that the fracture strength of the treated core increased by $22.9 \%$, the elastic modulus was reduced by $17.9 \%$, and the Poisson's ratio rose by $51.4 \%$. Therefore, it can be judged that the bionic wall-fixing agent led to a significant improvement of rock strength.

Table 2. Rock mechanical parameters of test core.

\begin{tabular}{cccc}
\hline \multirow{2}{*}{ Core } & \multicolumn{3}{c}{ Rock Mechanics Parameters } \\
\cline { 2 - 4 } & Breaking Strength (MPa) & Elastic Modulus (GPa) & Poisson's Ratio \\
\hline Before processing & 6.803 & 2.259 & 0.035 \\
After processing & 8.361 & 1.855 & 0.053 \\
\hline
\end{tabular}

\subsubsection{Suppression Performance}

\section{Linear Expansion Experiment}

According to the experimental results obtained from the linear expansion of mudstone core in different wall-fixing agents, the swelling volume of mudstone core in clear water is $3.87 \mathrm{~mm}$, and the swelling volume in $0.5 \%$ bionic wall-fixing agent solution is merely $1.62 \mathrm{~mm}$, down by $58.14 \%$. Compared with similar experiments in other papers, the wall-fixing agent was more effective [39-41].

\section{Rolling Recycling Experiment}

Figure 7 shows the preparation of different treatment solution at $150{ }^{\circ} \mathrm{C}$ under the conditions of a rock cutting rolling recovery experiment. It can be seen from Figure 7 that the rolling recovery rate of shale cuttings in the bionic wall-fixing agent solution reached $83.04 \%$, while the rolling recovery rate was higher compared with other domestic and foreign advanced inhibitors of the same concentration. Moreover, the recovery value of bionic wall-fixing agent solution was approximately equal to or higher than that of other common additives [42-44].

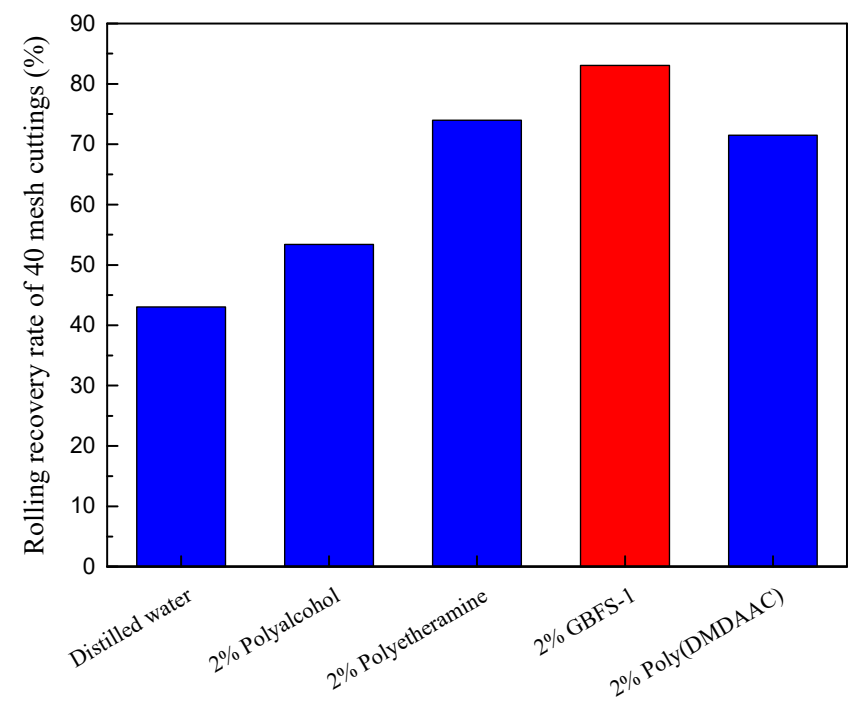

Figure 7. Rolling recovery rate evaluation.

In summary, the biomimetic wall-fixing agent developed by simulating the functional group of marine mussel adhesion protein can be used to generate a hydrogel with strong adhesion and cohesion 
through chelation and cross-linking reaction with the surface $\mathrm{Ca}^{2+}, \mathrm{Mg}^{2+}$ plasma, etc. It improves the cementation strength of shale and inhibits the hydration expansion of clay minerals.

\subsection{Using the Mucus Secreted by Earthworms as a Model to Develop Bionic Bonding Lubricants}

3.2.1. Development of Bionic Bonded Lubricants Based on the Principle of Earthworms Secreting Mucus

Invertebrate earthworms can move freely in the soil, and they are not clay, because the mucus secreted by the body surface has a good viscosity reduction and drag reduction function, which is related to the size and shape of the body, surface morphology and material composition, and the hydrophobicity of the body surface [15,45-47]. The higher the surface hydrophobicity and negative potential, the better the viscosity reduction and drag reduction effect. The surface of its body contains $\mathrm{P}, \mathrm{Si}, \mathrm{S}, \mathrm{Na}, \mathrm{Mg}, \mathrm{K}, \mathrm{Ca}$ and other trace elements mainly in the form of inorganic salts. Resistance is favorable. Therefore, bionic design can be carried out from two perspectives to achieve viscosity reduction and resistance reduction. One is to make surface modification to the solid materials with low surface energy polymer materials for them to possess strong hydrophobic properties. The other is that the bionics on the surface of solid materials composition design, in order to achieve the effect of reducing viscosity and resistance.

In the course of drilling, the movement of the drill bit and drilling tool in the stratum is highly similar to that of soil animals inhabiting the soil. Therefore, in line with the principle of reducing viscosity and drag of soil animals, the adsorption groups $-\mathrm{NH}_{2}$ and -COO- were taken as the reactive functional groups for esterification reaction, and the research and development can form metal chelate rings and multiple hydrogen bonds with the well wall and drilling tool surface. It can be reversed from hydrophilic to hydrophobic, and contains a trace amount of S, P, and other extreme pressure elements. The bionic bonding lubricant is effective in controlling the inherent eddy current in the flow interface, reducing the friction at the time of drilling, and improving the outcome of mechanical drilling. Thus, the overall efficiency of speed and drilling can be enhanced.

According to the infrared characterization of the biomimetic bonding lubricant shown in Figure 8, the characteristic peak of methyl- $\mathrm{CH}_{3}$ - stretching vibration is $2924.9 \mathrm{~cm}^{-1}$ while the characteristic peak of methylene- $\mathrm{CH}_{2}$ - stretching vibration is $2853.6 \mathrm{~cm}^{-1}$. The characteristic peak of ester bond -COO- in $-\mathrm{C}=\mathrm{O}$ is $1741.9 \mathrm{~cm}^{-1}$, the peak of methyl- $\mathrm{CH}_{3}$-deformation vibration absorption is $1463.9 \mathrm{~cm}^{-1}$, and the vibration absorption peak of the $\mathrm{C}-\mathrm{O}$ single bond in the ester bond is $1168.4 \mathrm{~cm}^{-1}$. Whereas, no absorption peaks can be found for carboxylic acid and the hydroxyl group, indicating the relatively complete esterification.

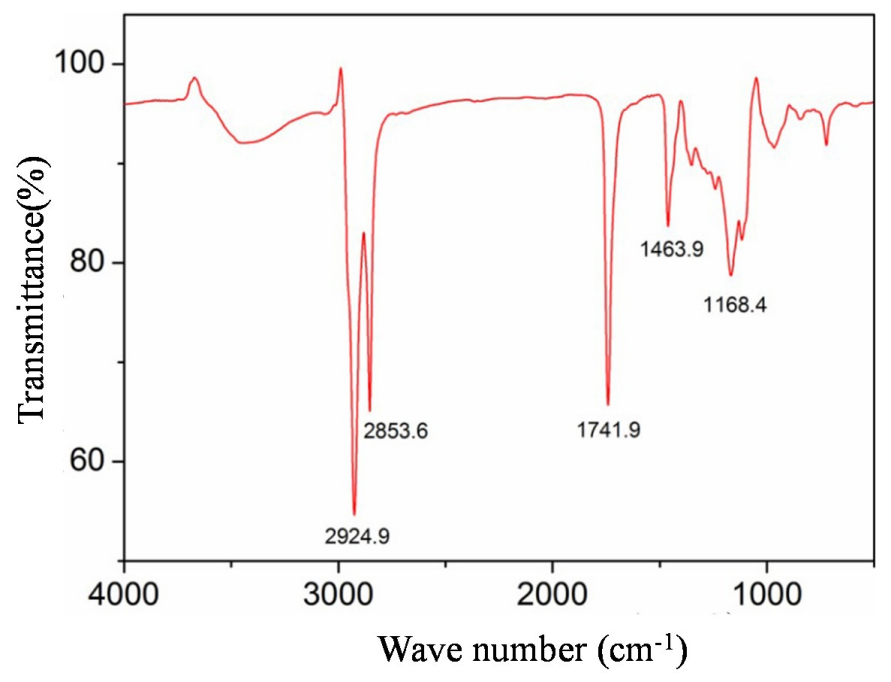

Figure 8. Infrared spectrum of bionic bonded lubricant. 


\subsubsection{Mechanism of action of bionic bonded lubricant}

\section{Bonding}

As a variety of amphiphilic molecule, the biomimetic bonding lubricant contains multi-branched polar adsorption groups, which can develop into a 'metal chelate ring' on the surface of metal drilling tools. Among them, the multi-branch polar adsorption groups $-\mathrm{NH}_{2}$ and -COO- in the biomimetic bonding lubricant play a role in the provision of paired electrons, while the Fe atoms on the surface of the metal drilling tool donate empty electron orbits, improving the strength of the lubricant adsorption film through chelation, as shown in Figure 9.

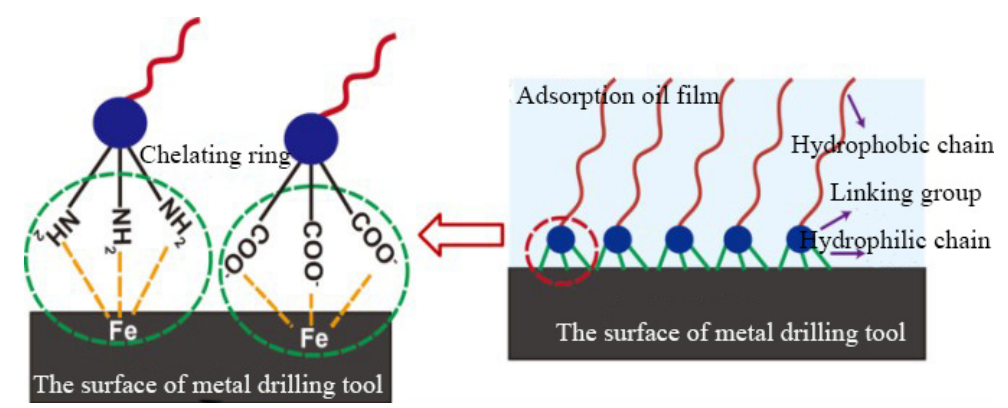

Figure 9. Chelation mechanism of bonded lubricant and drilling tool surface.

On the other hand, the bonded lubricant can generate a strong adsorption lubricating oil film on the well wall according to the principle of 'multiple hydrogen bonding'. Among them, the amino groups and carboxyl groups in the multi-branched polar adsorption groups in the bonded lubricant form 'multiple hydrogen bonds' with the $\mathrm{Si}-\mathrm{OH}$ and $\mathrm{Al}-\mathrm{OH}$ on the rock surface of the well wall, which is conducive to enhancing the absorption strength of the oil film and increasing the shear resistance performance of the lubricating oil film, as shown in Figure 10.

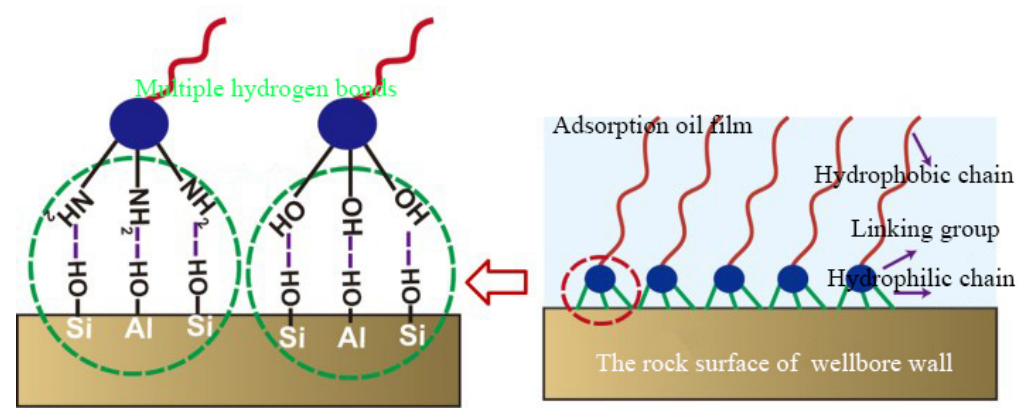

Figure 10. The principle of 'multiple hydrogen bonds' between bonded lubricant and rock surface.

Contact Angle Measurement

According to the measurement results of the water phase contact angle before and after the treatment of glass and steel sheets using different lubricants (Figures 11 and 12), foreign lubricants and bionic bonding lubricants have a certain degree of adsorption on the surface of glass and steel sheets, thus improving hydrophobicity. However, the hydrophobic effect of the bionic bonded lubricant is very significant, and is much greater than that of foreign advanced lubricants. 


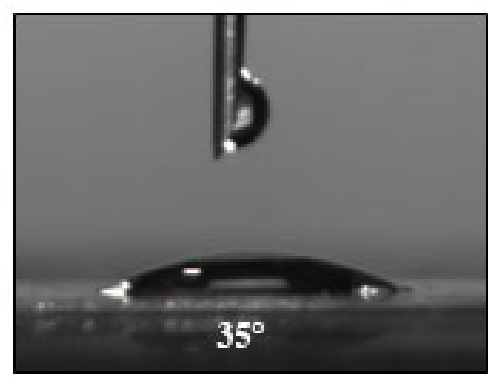

(a)

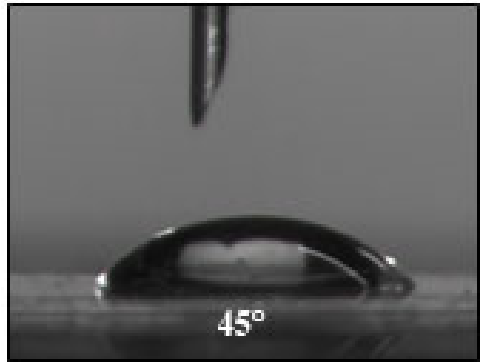

(b)

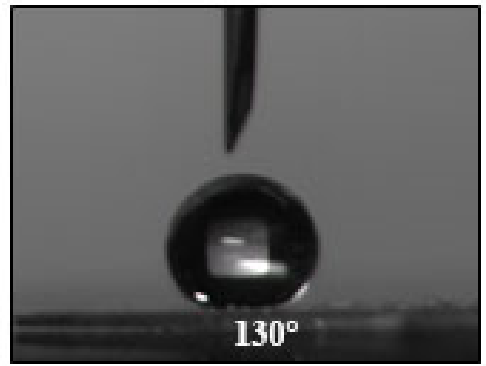

(c)

Figure 11. Compared with foreign countries, the difference of water phase contact angle of bionic bonding lubricant on the surface of glass sheet ((a) blank; (b) advanced lubricants DFL(Eco Global Solutios); (c) bionic bonded lubricant).

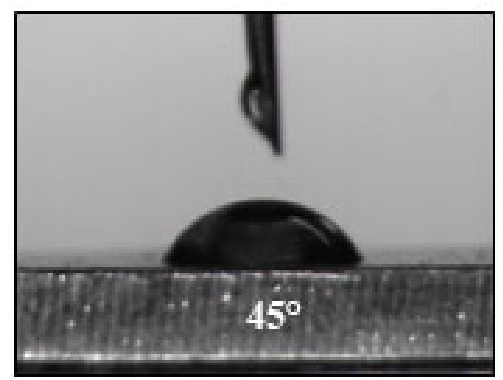

(a)

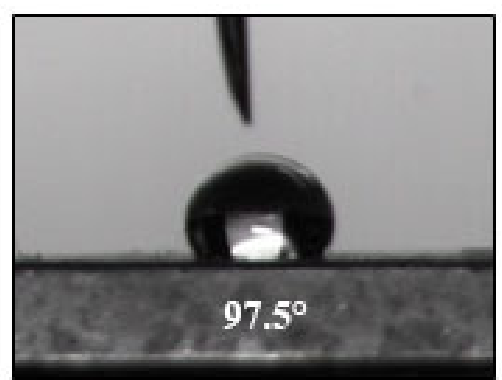

(b)

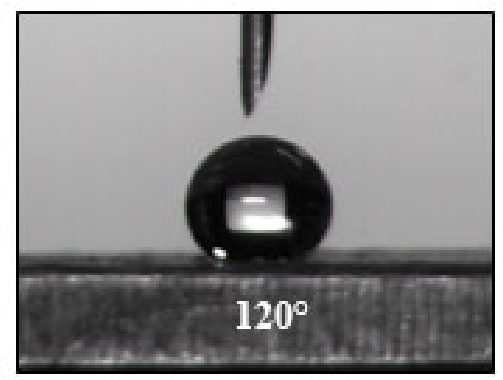

(c)

Figure 12. Compared with foreign countries, the difference of water phase contact angle of bionic bonding lubricant on the surface of steel sheet ((a) blank; (b) advanced lubricants DFL; (c) bionic bonded lubricant).

Therefore, the biomimetic bonding lubricant generated a film that possessed strong hydrophobicity, high strength and high lubricity due to the interaction of the 'metal chelate ring' and 'multiple hydrogen bonds' with the solid surface. Earthworms have a similar mechanism of viscosity reduction and resistance reduction.

\subsubsection{Performance Evaluation of Bionic Bonded Lubricant}

In this paper, the extreme pressure lubrication coefficient, four-ball friction test, and filter cake adhesion coefficient were applied to comparatively evaluate the lubricating effect of the bionic bond lubricant against the commonly used lubricants.

\section{Coefficient of Extreme Pressure Friction}

To obtain the base slurry, $4 \%$ bentonite and $0.2 \%$ sodium carbonate were added into deionized water and stirred at $1200 \mathrm{rpm}$ for $24 \mathrm{~h}$. Afterwards, $1 \%$ different lubricants were added into $4 \%$ base slurry, and extreme pressure (EP) lubricator was used to measure their extreme pressure lubrication coefficient, as shown in Table 3, which indicates that the lubrication effect of the bionic bonding lubricant is clearly superior to other commonly used lubricants both at home and abroad, and that it does not foam. In comparison with the blank base slurry, the reduction rate of the extreme pressure friction coefficient was $83.3 \%$ before aging and $90.4 \%$ after aging. Moreover, the lubricating effect after high temperature hot rolling was improved. 
Table 3. Lubricity of different lubricants in base slurry.

\begin{tabular}{|c|c|c|c|c|}
\hline Condition & Sample & $\begin{array}{c}\text { EP } \\
\text { Coefficient } \\
\text { of Friction }\end{array}$ & $\begin{array}{c}\text { Friction } \\
\text { Coefficient } \\
\text { Reduction Rate }\end{array}$ & Yes or No Foams \\
\hline \multirow{7}{*}{$\begin{array}{l}\text { Before } \\
\text { aging }\end{array}$} & $4 \%$ base slurry & 0.54 & - & No \\
\hline & $4 \%$ base slurry $+1 \%$ PF-lube & 0.32 & $40.7 \%$ & Slight blistering \\
\hline & $4 \%$ base slurry $+1 \% \mathrm{CX}-300 \mathrm{H}$ & 0.16 & $70.4 \%$ & Severe blistering \\
\hline & $4 \%$ base slurry $+1 \%$ PF-lube & 0.31 & $42.6 \%$ & Slight blistering \\
\hline & $4 \%$ base slurry $+1 \%$ Grandoil & 0.22 & $59.3 \%$ & blistering \\
\hline & $4 \%$ base slurry $+1 \%$ DFL & 0.10 & $81.5 \%$ & Slight blistering \\
\hline & $\begin{array}{c}4 \% \text { base slurry }+1 \% \text { bionic } \\
\text { bonded lubricant }\end{array}$ & 0.09 & $83.3 \%$ & No \\
\hline \multirow{7}{*}{$\begin{array}{l}\text { After } \\
\text { aging }\end{array}$} & $4 \%$ base slurry & 0.52 & - & No \\
\hline & $4 \%$ base slurry $+1 \%$ PF-lube & 0.32 & $38.5 \%$ & $\begin{array}{l}\text { Obviously } \\
\text { blistering }\end{array}$ \\
\hline & $4 \%$ base slurry $+1 \% \mathrm{CX}-300 \mathrm{H}$ & 0.15 & $71.2 \%$ & Severe blistering \\
\hline & $4 \%$ base slurry $+1 \%$ PF-lube & 0.13 & $75.0 \%$ & $\begin{array}{l}\text { Obviously } \\
\text { blistering }\end{array}$ \\
\hline & $4 \%$ base slurry $+1 \%$ Grandoil & 0.11 & $78.8 \%$ & Blistering \\
\hline & $4 \%$ base slurry $+1 \%$ DFL & 0.08 & $84.6 \%$ & Slight blistering \\
\hline & $\begin{array}{c}4 \% \text { base slurry }+1 \% \text { bionic } \\
\text { bonded lubricant }\end{array}$ & 0.05 & $90.4 \%$ & No \\
\hline
\end{tabular}

\section{Comparison of Filter Cake Adhesion Coefficient}

The NF-2 adhesion coefficient tester was used to measure the reduction rate of adhesion torque of different lubricants to $4 \%$ fresh water-based slurry filter cake, as shown in Table 4 . It can be seen from the table that the bionic bonding lubricant is effective in significantly improving the lubricating performance of the filter cake in fresh water-based slurry. The reduction rate of the filter cake adhesion coefficient at $1 \%$ dosage exceeds $62 \%$ before and after aging.

Table 4. The adhesion coefficient of bonded lubricant filter cake compared with other lubricants at home and abroad.

\begin{tabular}{ccccc}
\hline Sample & \multicolumn{2}{c}{ Before Aging } & \multicolumn{2}{c}{ After Aging } \\
& $\begin{array}{c}\text { Coefficient of } \\
\text { Adhesion }\end{array}$ & $\begin{array}{c}\text { Reduction } \\
\text { Rate }\end{array}$ & $\begin{array}{c}\text { Coefficient of } \\
\text { Adhesion }\end{array}$ & $\begin{array}{c}\text { Reduction } \\
\text { Rate }\end{array}$ \\
\hline $\begin{array}{c}\text { Ad base slurry } \\
4 \% \text { base slurry + 1\% PF-lube }\end{array}$ & 0.1225 & - & 0.1098 & - \\
$4 \%$ base slurry + 1\% CX-300H & 0.0845 & $31.0 \%$ & 0.0676 & $38.5 \%$ \\
$4 \%$ base slurry + 1\% PF-lube & 0.0592 & $51.7 \%$ & 0.0592 & $46.2 \%$ \\
$4 \%$ base slurry + 1\% Grandoil & 0.0676 & $44.8 \%$ & 0.0465 & $57.7 \%$ \\
$4 \%$ base slurry + 1\% DFL & 0.0549 & $51.7 \%$ & 0.0448 & $59.2 \%$ \\
$4 \%$ base slurry + 1\% bionic & 0.0465 & $55.2 \%$ & 0.0465 & $57.7 \%$ \\
bonded lubricant & & $62.1 \%$ & 0.0380 & $65.4 \%$ \\
\hline
\end{tabular}

Flow Resistance Reduction Rate in Base Slurry

A simulation was conducted regarding the flow of drilling fluid in a 6-meters-long circulation pipeline, and the pressure drop of the circulation line of the base slurry was measured at the same displacement under different dosages of bionic bonded lubricants, as shown in Table 5. It can be known from the experimental results that the flow resistance declines gradually as the amount of bonded lubricant increases. When the amount of bonded lubricant reaches $0.5 \%$, the flow resistance of the drilling fluid is reduced by as much as $12.5 \%$. 
Table 5. Flow resistance changes of simulated drilling fluid after adding a bonding lubricant.

\begin{tabular}{cccccccc}
\hline Lubricant dosage, $\%$ & 0 & 0.1 & 0.2 & 0.3 & 0.4 & 0.5 & 0.6 \\
\hline $\begin{array}{c}\text { Drilling fluid flow resistance } \\
\text { reduction rate, } \%\end{array}$ & 0 & 5.4 & 7.1 & 8.9 & 10.7 & 12.5 & 12.5 \\
\hline
\end{tabular}

Four-Ball Friction Evaluation

First, $0.5 \%$ bonding lubricant and advanced lubricants were added into clean water. Clean water is a blank group. A four-ball friction tester was used to grind for $30 \mathrm{~min}$ at a load of $150 \mathrm{~N}$ and a speed of $100 \mathrm{r} / \mathrm{min}$. Then, an observation was made using Quanta $200 \mathrm{~F}$ field launch Environmental scanning electron microscope and an analysis was conducted of the wear marks of the steel ball after a long time of grinding, with the experimental results shown in Figure 13. It can be seen from Figure 13 that the scratches in clear water are visible, with deeper furrows and the largest wear scar area observed. After the addition of lubricant, the diameter of wear scar was reduced, and the wear marks are the least obvious and the friction surface is the smoothest. However, after adding advanced lubricants at home and abroad, there are still more obvious scratches.

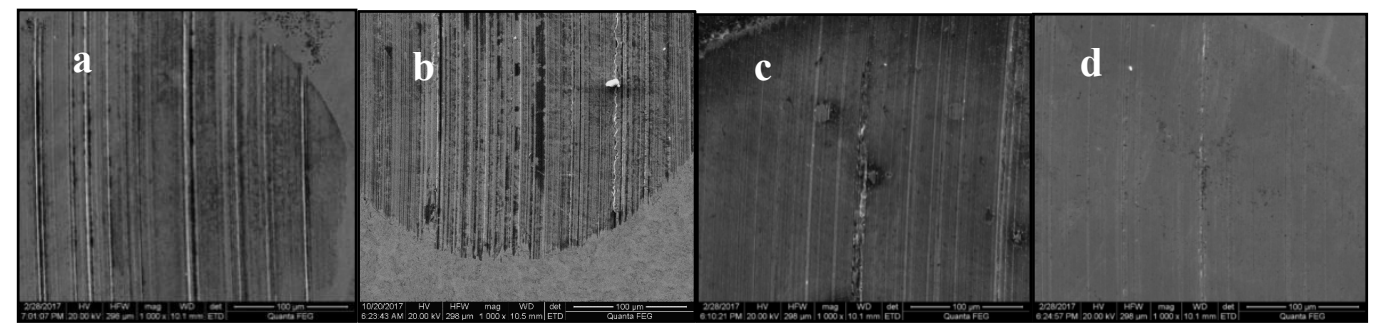

Figure 13. Four-ball friction scratches ((a) water; (b) PF-lube; (c) DFL; (d) bionic bonded lubricant).

In addition, in Figure 12, 0.5\% of each lubricant was added into 4\% base slurry for 20 min of grinding at a load of $150 \mathrm{~N}$ and a rotational speed of $150 \mathrm{r} / \mathrm{min}$. The coefficient of friction was measured in real time, with the results shown in Figure 14, which indicates that the addition of lubricant to $4 \%$ of the base slurry at room temperature is effective in significantly reducing the lubricating coefficient of the base slurry. Among them, the bonding lubricant performs best, with the friction coefficient reaching about 0.08. Moreover, DFL lubricant and PF-Lube lubricant products demonstrate excellent lubricating properties, with a coefficient of friction of approximately 1.2.

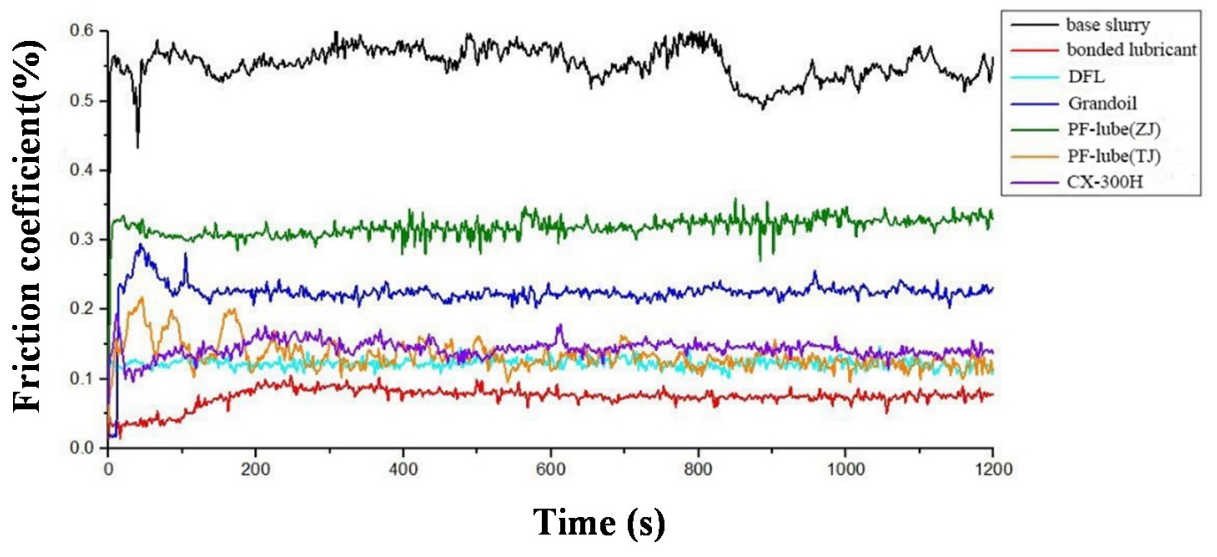

Figure 14. Real-time determination of friction coefficient.

Evaluation of Salt Resistance

First, $1 \%$ of the bonding lubricant was added into the $4 \%$ base slurry, followed by a certain amount of $\mathrm{NaCl}, \mathrm{CaCl}_{2}$ and $\mathrm{KCl}$, and the blank experimental group. Then, the extreme pressure lubrication 
coefficient of each group was measured before and after aging, as shown in Table 6, which indicates that the bionic bonding lubricant resists up to $30 \%$ of $\mathrm{NaCl}$ and $\mathrm{CaCl}_{2}$, and has good salt and calcium resistance. The aging conditions are $150{ }^{\circ} \mathrm{C}$ and $16 \mathrm{~h}$.

Table 6. Evaluation of salt and calcium resistance.

\begin{tabular}{|c|c|c|c|}
\hline Condition & Sample & $\begin{array}{l}\text { Coefficient of } \\
\text { Friction }\end{array}$ & $\begin{array}{l}\text { Friction Coefficient } \\
\text { Reduction Rate }\end{array}$ \\
\hline \multirow{8}{*}{$\begin{array}{l}\text { Before } \\
\text { aging }\end{array}$} & $4 \%$ base slurry & 0.52 & - \\
\hline & $4 \%$ base slurry $+1 \%$ lubricant & 0.08 & $84.6 \%$ \\
\hline & $4 \%$ base slurry $+10 \% \mathrm{NaCl}+1 \%$ lubricant & 0.08 & $84.6 \%$ \\
\hline & $4 \%$ base slurry $+20 \% \mathrm{NaCl}+1 \%$ lubricant & 0.08 & $84.6 \%$ \\
\hline & $4 \%$ base slurry $+30 \% \mathrm{NaCl}+1 \%$ lubricant & 0.09 & $82.7 \%$ \\
\hline & $4 \%$ base slurry $+10 \% \mathrm{CaCl}_{2}+1 \%$ lubricant & 0.08 & $84.6 \%$ \\
\hline & $4 \%$ base slurry $+20 \% \mathrm{CaCl}_{2}+1 \%$ lubricant & 0.09 & $82.7 \%$ \\
\hline & $4 \%$ base slurry $+30 \% \mathrm{CaCl}_{2}+1 \%$ lubricant & 0.08 & $84.6 \%$ \\
\hline \multirow{8}{*}{$\begin{array}{l}\text { After } \\
\text { aging }\end{array}$} & $4 \%$ base slurry & 0.51 & - \\
\hline & $4 \%$ base slurry $+1 \%$ lubricant & 0.05 & $90.2 \%$ \\
\hline & $4 \%$ base slurry $+10 \% \mathrm{NaCl}+1 \%$ lubricant & 0.05 & $90.2 \%$ \\
\hline & $4 \%$ base slurry $+20 \% \mathrm{NaCl}+1 \%$ lubricant & 0.06 & $88.2 \%$ \\
\hline & $4 \%$ base slurry $+30 \% \mathrm{NaCl}+1 \%$ lubricant & 0.07 & $86.3 \%$ \\
\hline & $4 \%$ base slurry $+10 \% \mathrm{CaCl}_{2}+1 \%$ lubricant & 0.05 & $90.2 \%$ \\
\hline & $4 \%$ base slurry $+20 \% \mathrm{CaCl}_{2}+1 \%$ lubricant & 0.06 & $88.2 \%$ \\
\hline & $4 \%$ base slurry $+30 \% \mathrm{CaCl}_{2}+1 \%$ lubricant & 0.10 & $80.4 \%$ \\
\hline
\end{tabular}

Evaluation of Temperature Resistance

$1 \%$ of the bonding lubricant was added into $4 \%$ of the base slurry for aging at different temperatures for $16 \mathrm{~h}$ each. Then, the lubricating coefficient of the aging base slurry was measured and compared, as shown in Table 7 , which indicates that after aging at $120^{\circ} \mathrm{C}$, the lubricity of the bonding lubricant was improved. Subsequently, as the temperature rose, the reduction rate of friction sparseness showed a slight decline, despite the retention of an excellent lubricating ability. Therefore, this bonding type lubricant has strong temperature resistance.

Table 7. Temperature resistance test.

\begin{tabular}{cccc}
\hline $\begin{array}{c}\text { Aging } \\
\text { Temperature }\end{array}$ & Sample & $\begin{array}{c}\text { Coefficient } \\
\text { of Friction }\end{array}$ & $\begin{array}{c}\text { Friction Coefficient } \\
\text { Reduction Rate }\end{array}$ \\
\hline Room temperature & $4 \%$ base slurry $+1 \%$ bonding lubricant & 0.54 & - \\
\hline Aging at $120{ }^{\circ} \mathrm{C}$ for & $4 \%$ base slurry & 0.09 & $83.3 \%$ \\
$16 \mathrm{~h}$ & $4 \%$ base slurry $+1 \%$ bonding lubricant & 0.04 & - \\
\hline Aging at $150{ }^{\circ} \mathrm{C}$ for & $4 \%$ base slurry & 0.50 & $92.3 \%$ \\
$16 \mathrm{~h}$ & $4 \%$ base slurry $+1 \%$ bonding lubricant & 0.04 & - \\
\hline Aging at $180{ }^{\circ} \mathrm{C}$ for & $4 \%$ base slurry & 0.50 & - \\
$16 \mathrm{~h}$ & $4 \%$ base slurry $+1 \%$ bonding lubricant & 0.05 & $90.0 \%$ \\
\hline Aging at $200{ }^{\circ} \mathrm{C}$ for & $4 \%$ base slurry & 0.48 & - \\
$16 \mathrm{~h}$ & $4 \%$ base slurry $+1 \%$ bonding lubricant & 0.07 & $85.4 \%$ \\
\hline Aging at $220{ }^{\circ} \mathrm{C}$ for & $4 \%$ base slurry & 0.45 & - \\
$16 \mathrm{~h}$ & $4 \%$ base slurry $+1 \%$ bonding lubricant & 0.07 & $84.4 \%$ \\
\hline
\end{tabular}

Thus, it can be known that the biomimetic bonding lubricant reduces the friction coefficient between the solid particles in the drilling tool and drilling fluid and the rock shaft wall through 
the adsorption onto the surface of the drilling tool and the rock, therefor resulting in better lubricity property compared with other lubricants reported in previous articles [48-51].

\section{Discussion}

\subsection{Bionic Enhanced Wellbore and Super-Lubricated Water-Based Drilling Fluid Technology Establishment and} Field Application

With bionic wall-fixing agent and bionic bonding lubricant as the core, combined with the drilling situation, according to the "chemical-engineering-geology" integrated thinking, and supporting other treatment agents, a bionic reinforced wellbore and strong lubricating water-based drilling were formed.

The basic formula of bionic reinforced wellbore and strong lubricating water-based drilling fluid is detailed as $0.15 \%$ base slurry $+2-3 \%$ bionic wall-fixing agent $+1-2 \%$ bonding lubricant $+1-3 \%$ fluid loss control agent $+7 \% \mathrm{KCl}+$ barite (adjusted to the required density).

The typical oil-based drilling fluid is detailed as $80 \%$ No.3 white oil $+3 \%$ auxiliary emulsifier $+1 \%$ main emulsifier $+4 \%$ wetting agent $+20 \%$ calcium chloride solution $+1 \%$ organic clay $+0.5 \%$ cutting agent $+4 \%$ fine calcium carbonate $+2 \%$ plugging fluid loss agent + barite (adjusted to the required density).

4.1.1. Performance Evaluation of Bionic Reinforced Wellbore and Strong Lubricating Water-Based Drilling Fluid

\section{Evaluation of Salt Resistance}

$\mathrm{NaCl}$ and $\mathrm{CaCl}_{2}$ of different amounts were added into the basic system of the bionic water-based drilling fluid for investigating its salt and calcium resistance. From Table 8, it can be seen that with $30 \% \mathrm{NaCl}$ and $0.5 \% \mathrm{CaCl}_{2}$ added, the rheological properties of the system vary less significantly, the fluid loss still meets the requirements despite a slight increases, and it shows a strong salt and calcium resistance.

Table 8. Anti-salt and anti-calcium properties of drilling fluid system.

\begin{tabular}{cccccc}
\hline Formula & $\begin{array}{c}\mathrm{AV} \\
\mathbf{m P a} \cdot \mathbf{s}\end{array}$ & $\begin{array}{c}\text { PV } \\
\mathbf{m P a} \cdot \mathbf{s}\end{array}$ & $\begin{array}{c}\text { YP } \\
\mathbf{P a}\end{array}$ & $\mathbf{Y P / P V}$ & $\begin{array}{c}\text { HTHP } \\
\mathbf{m L}\end{array}$ \\
\hline Bionic water-based drilling fluid & 37.5 & 35 & 2.5 & 0.0714 & 5 \\
$\begin{array}{c}\text { system } \\
\begin{array}{c}\text { Bionic water-based drilling fluid } \\
\text { system + 30\% NaCl }\end{array}\end{array}$ & 40 & 32 & 8 & 0.2500 & 8 \\
$\begin{array}{c}\text { Bionic water-based drilling fluid } \\
\text { system + 0.5\% } \mathrm{CaCl}_{2}\end{array}$ & 36.5 & 32 & 4.5 & 0.1406 & 8.4 \\
\hline
\end{tabular}

Evaluation of Temperature Resistance

The field mud in Xinjiang Oilfield was taken (System 1\#), then System 1\# was transformed into a bionic reinforced wellbore and strong lubricating water-based drilling fluid (System 2\#), after aging at $80^{\circ} \mathrm{C}, 100^{\circ} \mathrm{C}$, and $120^{\circ} \mathrm{C}$ for $16 \mathrm{~h}$. The measured performance is shown in Table 9 , which indicates that, as the temperature rises, the viscosity of the system declines slightly, while the filtration loss at medium pressure, high temperatures, and high pressure slightly increases. Overall, the temperature resistance of the bionic water-based drilling fluid system exceeds $150{ }^{\circ} \mathrm{C}$. As for high-temperature and high-pressure filtration loss, the test temperature was set to $80^{\circ} \mathrm{C}, 100{ }^{\circ} \mathrm{C}$, and $120^{\circ} \mathrm{C}$. 
Table 9. Test results and evaluation table after system aging.

\begin{tabular}{|c|c|c|c|c|c|c|c|c|c|}
\hline \multirow{2}{*}{$\begin{array}{c}\text { Temperature, } \\
{ }^{\circ} \mathrm{C}\end{array}$} & \multirow{2}{*}{$\begin{array}{l}\text { System } \\
\text { Number }\end{array}$} & \multirow{2}{*}{$\mathrm{G} 10^{\prime \prime} \mathrm{Pa}$} & \multirow{2}{*}{ G10'Pa } & \multirow{2}{*}{$\begin{array}{c}\mathrm{AV} \\
\mathrm{mPa} \cdot \mathrm{s}\end{array}$} & \multirow{2}{*}{$\begin{array}{c}\mathrm{PV} \\
\mathrm{mPa} \cdot \mathrm{s}\end{array}$} & \multirow{2}{*}{ YPPa } & \multicolumn{2}{|c|}{ Fluid Loss, $\mathrm{mL}$} & \multirow{2}{*}{$\begin{array}{c}\rho, \\
\mathrm{g} / \mathrm{cm}^{3}\end{array}$} \\
\hline & & & & & & & API & HTHP & \\
\hline \multirow{2}{*}{80} & 1\# & 1 & 5 & 29 & 24 & 5 & 3.2 & 9.8 & 1.29 \\
\hline & 2\# & 1 & 4.5 & 27 & 22 & 5 & 3 & 9.6 & 1.29 \\
\hline \multirow{2}{*}{120} & $1 \#$ & 1 & 5 & 28 & 23 & 5 & 3.2 & 9.8 & 1.29 \\
\hline & 2\# & 1 & 4 & 25.5 & 20 & 5.5 & 3.0 & 9.6 & 1.29 \\
\hline \multirow{2}{*}{150} & $1 \#$ & 1 & 5 & 27.5 & 22 & 5.5 & 3 & 9.8 & 1.29 \\
\hline & $2 \#$ & 1 & 4 & 24.5 & 19 & 5.5 & 3.4 & 10 & 1.29 \\
\hline
\end{tabular}

\section{Core Compressive Strength Evaluation}

1\# and 2\# drilling fluids were added into two aging tanks containing the same artificial core, for subsequent aging at $120^{\circ} \mathrm{C}$ for $16 \mathrm{~h}$. Then, the core was taken out, and the compressive strength of the core was measured, as shown in Table 10. It can be seen from the table that the strength of the core is improved by $14.11 \%$, thus achieving the purpose of strengthening.

Table 10. Conventional mechanical parameters of core.

\begin{tabular}{cccccc}
\hline $\begin{array}{c}\text { Core } \\
\text { Number }\end{array}$ & $\begin{array}{c}\text { Length } \\
(\mathbf{m m})\end{array}$ & $\begin{array}{c}\text { Diameter } \\
\mathbf{( m m )}\end{array}$ & Mass $\mathbf{( g )}$ & $\begin{array}{c}\text { Density } \\
\left(\mathbf{g} / \mathbf{c m}^{\mathbf{3}}\right)\end{array}$ & $\begin{array}{c}\text { Compressive } \\
\text { Strength } \mathbf{( M P a})\end{array}$ \\
\hline $2 \#$ & 50.18 & 24.78 & 45.20 & 1.87 & 4.101 \\
$4 \#$ & 50.18 & 24.44 & 42.36 & 1.80 & 4.68 \\
\hline
\end{tabular}

Environmental Performance Evaluation

According to the results of bio-toxicity and biodegradability tests shown in Table 11, the system constructed using the calcium drilling fluid system technology is safe, toxin-free and biodegradable.

Table 11. Environmental performance evaluation.

\begin{tabular}{cccccc}
\hline Sample & $\begin{array}{c}\mathrm{EC}_{50} \\
(\mathrm{mg} / \mathrm{L})\end{array}$ & $\begin{array}{c}\mathrm{COD}_{\mathrm{Cr}} \\
(\mathbf{m g} / \mathbf{L})\end{array}$ & $\begin{array}{c}\mathrm{BOD}_{5} \\
(\mathbf{m g} / \mathrm{L})\end{array}$ & BOD $_{5} / \mathrm{COD}_{\mathrm{Cr}}$ & Biodegradability \\
\hline $\begin{array}{l}\text { Water-based } \\
\text { drilling fluid }\end{array}$ & $3.18 \times 10^{4}$ & $1.32 \times 10^{5}$ & $2.54 \times 10^{4}$ & 0.192 & Degradable \\
\hline
\end{tabular}

\subsubsection{Performance Comparison with Typical Oil-Based Drilling Fluids}

\section{Basic Performance Comparison}

In Table 12, a comparison is performed of the basic performance of bionic reinforced wellbore and strong lubricating water-based drilling fluid and typical oil-based drilling fluid. From this table, it can be seen that the bionic water-based drilling fluid is characterized by lower apparent viscosity, better rheology, lower medium pressure filtration loss, and the same filter cake friction coefficient as oil-based drilling fluid. The drilling fluid density is $2.41 \mathrm{~g} / \mathrm{cm}^{3}$, the aging temperature is $130{ }^{\circ} \mathrm{C} \times 16 \mathrm{~h}$, the high-temperature and high-pressure temperature is $130^{\circ} \mathrm{C}$ and $3.5 \mathrm{MPa}$.

Table 12. Comparison of basic performance of drilling fluid.

\begin{tabular}{cccccccc}
\hline $\begin{array}{c}\text { Drilling Fluid } \\
\text { Type }\end{array}$ & $\begin{array}{c}\mathbf{F L}_{\mathrm{API}} \\
\mathbf{m L}\end{array}$ & $\begin{array}{c}\mathrm{AV} \\
\mathbf{m P a} \cdot \mathbf{s}\end{array}$ & $\begin{array}{c}\mathbf{P V} \\
\mathbf{m P a} \cdot \mathbf{s}\end{array}$ & $\begin{array}{c}\mathbf{Y P} \\
\mathbf{P a}\end{array}$ & $\begin{array}{c}\mathrm{GEL}, \\
\mathbf{P a} / \mathbf{P a}\end{array}$ & $\begin{array}{c}\mathrm{FL}_{\mathrm{HTHP}} \\
\mathbf{m L}\end{array}$ & $\begin{array}{c}\text { Friction } \\
\text { Coefficient }\end{array}$ \\
\hline $\begin{array}{c}\text { Bionic } \\
\text { water-based }\end{array}$ & 0 & 103 & 82 & 21 & $5.5 / 25$ & 2.4 & 0.0369 \\
Oil-based & 0.2 & 129.5 & 105 & 24.5 & $4.5 / 18$ & 2.4 & 0.0369 \\
\hline
\end{tabular}




\section{Inhibitory Comparison}

The inhibition performance of the two drilling fluids was evaluated using a rolling recovery and linear expansion method, as shown in Figure 15, which indicates that the inhibition of bionic water-based drilling fluids is comparable to that of typical oil-based drilling fluids, thus meeting the demanding requirements for inhibition performance in exceptional and complex oil and gas drilling processes such as dense and shale.

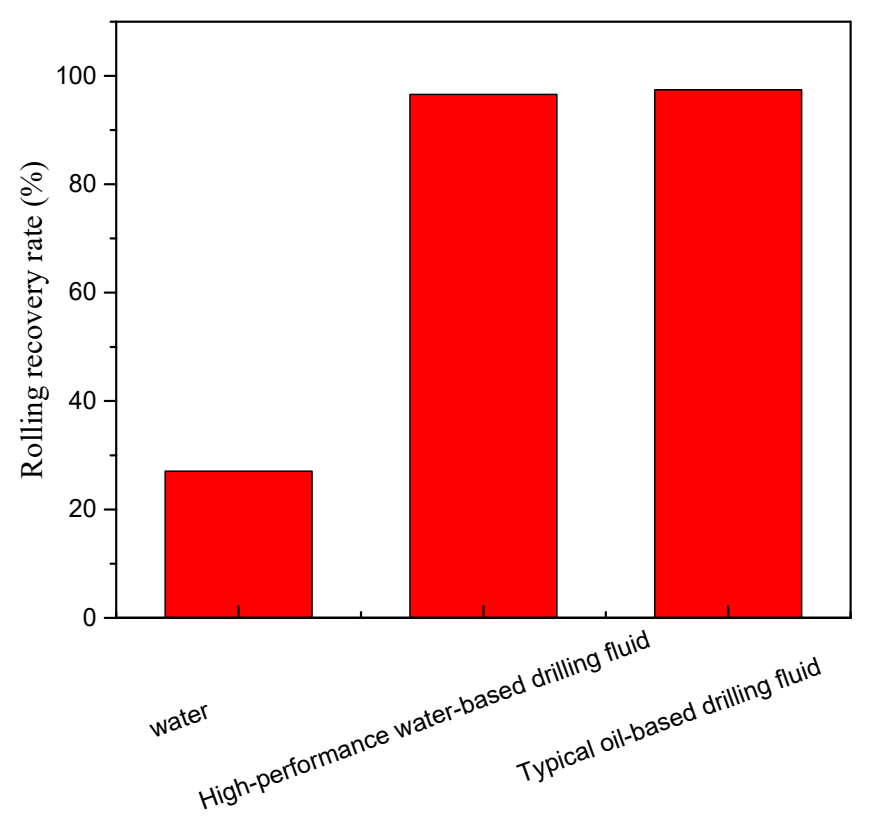

Figure 15. Evaluation of the inhibition performance of drilling fluid system.

As revealed by the above-mentioned evaluation, the bionic water-based drilling fluid possesses good rheology and filtration, with its inhibition and lubricity comparable to typical oil-based drilling fluids. Furthermore, it is environmentally friendly, which makes it effective in solving unconventional, tight gas, shale, and other unconventional gas. The bionic water-based drilling fluid performed more excellent performance than other reported drilling fluids [52-54].

\subsection{Field Application Effect}

At present, bionic reinforced wellbore and strong lubricating water-based drilling fluid have been widely applied in various unconventional and complex oil and gas wells both at home and abroad. Compared with the previous drilling fluid technology in the same block, the average rate of well collapse accidents is reduced by as much as $82.6 \%$, the accident rate of stuck drill is significantly reduced by $86.4 \%$, and the complication of stuck card is reduced by as much as $79.7 \%$. In the meantime, it was introduced by an internationally renowned company and used in the scale of tight gas wells in Yanan Pagoda, Zichang County, Ansai, and other regions. The average drilling speed was improved by more than $32.8 \%$, and the overall cost of drilling fluid was lowered by $42.3 \%$.

For example, the deployment of this technology prevented the drilling failure of the HW8003 tight oil horizontal well in the Junggar Basin. The avalanche collapse occurring in the borehole wall and the jamming was serious. The failure of the sidetracking of the well filling caused a total loss of 2.334354 million yuan in drilling fluid material cost and $25.58 \mathrm{~d}(614 \mathrm{~h})$ of lost time. The third wellbore was converted to this technology, and the drilling of the well suffered severe damaged twice. During the process, there were no complicated downhole conditions.

Prior to 2013, when drilling the horizontal section of Sulige Su 53 block, if mudstone layers were encountered, all accidents such as scoring, stuck pipe, and collapsed blocks would occur (Table 13) [41]. To solve this problem, polysulfonate drilling fluid system, silicone drilling fluid system, organic salt 
drilling fluid system, oil-based drilling fluid system, and so on, were trialed separately, but the outcome was not satisfactory. After 2013, this drilling fluid technology was applied to reduce downhole complex conditions or accidents to 0 , drilling rate was improved by $27 \%$, and drilling fluid unit cost was lowered by $36.4 \%$. Table 14 shows some of its applications [55].

Table 13. Complicated conditions caused by drilling fluid technologies for horizontal wells in Block Su 53.

\begin{tabular}{cccccc}
\hline Well Number & $\begin{array}{c}\text { Complex Situation } \\
\text { Type }\end{array}$ & $\begin{array}{c}\text { Lost } \\
\text { Time (h) }\end{array}$ & Well Number & Complex Type & $\begin{array}{c}\text { Lost } \\
\text { Time (h) }\end{array}$ \\
\hline Su53-70-28H & $\begin{array}{c}\text { Collapse and leakage } \\
\text { Collapsing and } \\
\text { scratching }\end{array}$ & 115 & Su53-78-12H & $\begin{array}{c}\text { Collapsing and } \\
\text { scratching }\end{array}$ & 15.5 \\
Su53-74-40H & 84 & Su53-78-12H & Collapse and leakage & 155 \\
Su53-74-40H & $\begin{array}{c}\text { Collapse and fill well } \\
\text { Collapsing and } \\
\text { scratching }\end{array}$ & 42.5 & Su53-78-24H1 & $\begin{array}{c}\text { Well collapse and drop } \\
\text { drill tools }\end{array}$ & 356 \\
Su53-74-41H & 79 & Su53-78-28H1 & Collapse and leakage & 187 \\
Su53-74-42H & $\begin{array}{c}\text { Well collapse, stuck } \\
\text { pipe }\end{array}$ & 9 & Su53-78-28H1 & Collapse and leakage & 210 \\
\hline
\end{tabular}

Notes: Data in this table comes from statistics of downhole complex accidents in Changqing Oilfield Sulige block in 2013.

Table 14. Part of the application wells in Block Su 53.

\begin{tabular}{|c|c|c|}
\hline Number & Well Number & Situation \\
\hline 1 & Su53-86-15H1 Well & $\begin{array}{l}\text { Solved the problems of frequent accidents and high drilling } \\
\text { fluid cost during the drilling of horizontal wells in the block, } \\
\text { creating the record of the fastest drilling speed and the shortest } \\
\text { construction period of the Great Wall Drilling Horizontal Wells } \\
\text { in Sulige Gas Field. }\end{array}$ \\
\hline 2 & Su53-86-15H Well & $\begin{array}{l}\text { 1. Creating a record of the continuous long section of mudstone } \\
(1028 \mathrm{~m}) \text {, there is no record of the complex conditions and } \\
\text { the fastest drilling speed related to drilling fluid; } \\
\text { 2. Compared with other wells containing mudstone, } \\
\text { the average ROP of the whole well increased by } 35.8 \% \text { and } \\
\text { the drilling fluid cost decreased by } 42.3 \%) \text {. }\end{array}$ \\
\hline 3 & Su53-70-22H Well & $\begin{array}{c}\text { The average ROP increased by } 37.2 \% \text {, the drilling fluid cost } \\
\text { was reduced by more than } 31.8 \% \text {, and there were no accidents } \\
\text { related to drilling fluid. }\end{array}$ \\
\hline
\end{tabular}

Notes: Data in this table comes from statistics of downhole complex accidents in Changqing Oilfield Sulige block in 2020 .

\section{Conclusions}

(1) Bionics is introduced into the field of drilling fluids. By studying and imitating the function, the principle and composition of marine mussel secretion of adhesion proteins and earthworm secretion of mucus, the biomimetic wall-fixing agent and biomimetic bonding lubricant developed in the borehole wall, respectively, succeeded in chelating and cross-linking the rock to form a bio-gel network, and forming a smooth film through the bond between the rock and the surface of the drilling tool to achieve the purpose of strengthening the wellbore and strong lubrication.

(2) Compared with the advanced technology introduced from abroad, the strength of the rock is not only reduced but increased by more than $14 \%$, the friction reduction rate is improved by $12.3 \%$. The rolling recovery rate of shale cuttings in the bionic wall-fixing agent solution reached $83.04 \%$. The reduction rate of the filter cake adhesion coefficient at $1 \%$ dosage exceeds $62 \%$ before and after aging. 
(3) Compared with the previous drilling fluid technology in the same block, the average rate of well collapse accidents is reduced by as much as $82.6 \%$, the accident rate of stuck drill is significantly reduced by $86.4 \%$, and the complication of stuck card is reduced by as much as $79.7 \%$. The average drilling speed was improved by more than $32.8 \%$, and the overall cost of drilling fluid was lowered by $42.3 \%$.

Author Contributions: Conceptualization, G.J. and Y.H.; methodology, X.Q.; investigation, X.Q.; resources, X.L.; data curation, T.D.; writing — original draft preparation, X.Q.; writing—review and editing, G.J.; visualization, Y.H.; supervision, G.J.; project administration, G.J.; funding acquisition, X.L. All authors have read and agreed to the published version of the manuscript.

Funding: This work was supported by the National Science Foundation of China (grant No. 51874329), the National Science and Technology Major Project of China (2016ZX05040-005 and 2017ZX05009), National Natural Science Innovation Population of China (Grant No. 51821092), Project of The Fourth Branch Company of CNPC Bohai Drilling Engineering Company Limited (2019Z22K) and Project of CNPC Engineering Technology R\&D Company Limited (2019D-4507).

Acknowledgments: Authors wish to acknowledge assistance and encouragement from colleagues (Changyu Ni and Pengcheng Li).

Conflicts of Interest: The authors declare no conflict of interest.

\section{References}

1. Mahmoud, H.; Hamza, A.; Nasser, M.S.; Hussein, I.A.; Ahmed, R.; Karami, H. Hole cleaning and drilling fluid sweeps in horizontal and deviated wells: Comprehensive review. J. Pet. Sci. Eng. 2020, 186, 106748. [CrossRef]

2. Akpan, E.U.; Enyi, G.C.; Nasr, G.; Yahaya, A.A.; Ahmadu, A.A.; Saidu, B. Water-based drilling fluids for high-temperature applications and water-sensitive and dispersible shale formations. J. Pet. Sci. Eng. 2019, 175, 1028-1038. [CrossRef]

3. Saleh, T.A.; Ibrahim, M.A. Advances in functionalized Nanoparticles based drilling inhibitors for oil production. Energy Rep. 2019, 5, 1293-1304. [CrossRef]

4. Huang, T.; Cao, L.; Cai, J.; Xu, P. Experimental investigation on rock structure and chemical properties of hard brittle shale under different drilling fluids. J. Pet. Sci. Eng. 2019, 181, 106185. [CrossRef]

5. Xie, B.Q.; Zhang, X.B.; Li, Y.G.; Liu, W.; Luo, M.W. Application a novel thermo-sensitive copolymer as a potential rheological modifier for deep-water water-based drilling fluids. Colloids Surf. A Physicochem. Eng. Asp. 2019, 581, 123848.

6. Magalhães, S.; Borges, R.; Calçada, L.; Scheid, C.; Folsta, M.; Waldmann, A.; Martins, A. Development of an expert system to remotely build and control drilling fluids. J. Pet. Sci. Eng. 2019, 181, 106033. [CrossRef]

7. Luan, J.; Dong, P.; Zheng, J. Experimental studies on reaction laws during the process of air injection into the oil reservoirs with low permeability. J. Pet. Sci. Eng. 2020, 194, 107526. [CrossRef]

8. Song, Y.; Li, Z.; Jiang, Z.; Luo, Q.; Liu, D.; Gao, Z. Progress and development trend of unconventional oil and gas geological research. Pet. Explor. Dev. 2017, 44, 675-685. [CrossRef]

9. Wang, Z.; Tong, S.; Wang, C.; Zhang, J.; Fu, W.; Sun, B. Hydrate deposition prediction model for deep-water gas wells under shut-in conditions. Fuel 2020, 275, 117944. [CrossRef]

10. Zheng, L.; Chen, B.; Zhang, Z.; Tang, J.; Sun, H. Anti-collapse mechanism of CBM fuzzy-ball drilling fluid. Nat. Gas Ind. B 2016, 3, 152-157. [CrossRef]

11. Brandon, N.; Panesar, S.; Bonanos, N.; Fogarty, P.; Mahmood, M. The effect of cathodic currents on friction and stuck pipe release in aqueous drilling muds. J. Pet. Sci. Eng. 1993, 10, 75-82. [CrossRef]

12. Al Sandouk-Lincke, N.A.; Schwarzbauer, J.; Antic, V.; Antić, M.; Caase, J.; Grünelt, S.; Reßing, K.; Littke, R. Off-line-pyrolysis-gas chromatography-mass spectrometry analyses of drilling fluids and drill cuttings-Identification of potential environmental marker substances. Org. Geochem. 2015, 88, 17-28. [CrossRef]

13. Beydokhti, A.K.; Hajiabadi, S.H. Rheological investigation of smart polymer/carbon nanotube complex on properties of water-based drilling fluids. Colloids Surf. A Physicochem. Eng. Asp. 2018, 556, 23-29. [CrossRef]

14. Zhong, H.; Shen, G.; Qiu, Z.; Lin, Y.; Fan, L.; Xing, X.; Li, J. Minimizing the HTHP filtration loss of oil-based drilling fluid with swellable polymer microspheres. J. Pet. Sci. Eng. 2019, 172, 411-424. [CrossRef] 
15. Paswan, B.K.; Mahto, V. Development of environment-friendly oil-in-water emulsion based drilling fluid for shale gas formation using sunflower oil. J. Pet. Sci. Eng. 2020, 191, 107129. [CrossRef]

16. Xu, Z.; Song, X.; Li, G.; Zhu, Z.; Zhu, B. Gas kick simulation in oil-based drilling fluids with the gas solubility effect during high-temperature and high-pressure well drilling. Appl. Therm. Eng. 2019, 149, 1080-1097. [CrossRef]

17. Ke, G.; Youhong, S.; Runfeng, G.; Liang, X.; Chuanliu, W.; Yumin, L. Application and prospect of bionic non-smooth theory in drilling engineering. Pet. Explor. Dev. 2009, 36, 519-541. [CrossRef]

18. Jiang, J.; Peng, X.; Li, J.; Chen, Y. A comparative study on the performance of typical types of bionic groove dry gas seal based on bird wing. J. Bionic Eng. 2016, 13, 324-334. [CrossRef]

19. Yin, B.; Xu, T.; Hou, D.; Zhao, E.; Hua, X.; Han, K.; Zhang, Y.; Zhang, J. Superhydrophobic anticorrosive coating for concrete through in-situ bionic induction and gradient mineralization. Constr. Build. Mater. 2020, 257, 257. [CrossRef]

20. Chen, C.; Zhao, Y.; Mei, H.; Kong, Z.; Mao, M.; Cheng, L. Excellent lubrication properties of 3D printed ceramic bionic structures. Ceram. Int. 2020. [CrossRef]

21. Kamil, N.; Ewa, L.; Piotr, S.; Katarzyna, E.N.; Jacek, P.S. Bionic eye review-An update. J. Clin. Neurosci. 2020, 78, 8-19.

22. Han, J.; Hui, Z.; Tian, F.; Chen, G. Review on bio-inspired flight systems and bionic aerodynamics. Chin. J. Aeronaut. 2020. [CrossRef]

23. Zhan, X.; Yi, P.; Liu, Y.; Jiang, Y.; Jin, Y.; Dong, G.; Zhang, Y. Effects of texture spacing and bulges of bionic sinusoidal texture on the adhesion properties and fracture mechanism of plasma-sprayed coatings. Surf. Coat. Technol. 2020, 393, 125772. [CrossRef]

24. Xie, Y.; Bai, H.; Liu, Z.; Chen, N. A Novel Bionic Structure Inspired by Luffa Sponge and Its Cushion Properties. Appl. Sci. 2020, 10, 2584. [CrossRef]

25. Zheng, L.; Su, G.; Li, Z.; Peng, R.; Wang, L.; Wei, P.; Han, S. The wellbore instability control mechanism of fuzzy ball drilling fluids for coal bed methane wells via bonding formation. J. Nat. Gas Sci. Eng. 2018, 56, 107-120. [CrossRef]

26. Shen, Y.; Liu, H.; Wang, H.; Wu, H. Wellbore instability induced by alternating water injection and well washing with an elasto-plastic erosion model. J. Nat. Gas Sci. Eng. 2015, 27, 1863-1870. [CrossRef]

27. Dokhani, V.; Yu, M.; Bloys, B. A wellbore stability model for shale formations: Accounting for strength anisotropy and fluid induced instability. J. Nat. Gas Sci. Eng. 2016, 32, 174-184. [CrossRef]

28. Yu, M.; Chenevert, M.E.; Sharma, M.M. Chemical-mechanical wellbore instability model for shales: Accounting for solute diffusion. J. Pet. Sci. Eng. 2003, 38, 131-143. [CrossRef]

29. Zhao, X.; Qiu, Z.; Wang, M.; Xu, J.; Huang, W. Experimental investigation of the effect of drilling fluid on wellbore stability in shallow unconsolidated formations in deep water. J. Pet. Sci. Eng. 2019, 175, 595-603. [CrossRef]

30. Rafieepour, S.; Zamiran, S.; Ostadhassan, M. A cost-effective chemo-thermo-poroelastic wellbore stability model for mud weight design during drilling through shale formations. J. Rock Mech. Geotech. Eng. 2020. [CrossRef]

31. Chen, X.; Huang, Y.; Yang, G.; Li, J.-X.; Wang, T.; Schulz, O.; Jennings, L. Polydopamine Integrated Nanomaterials and Their Biomedical Applications. Curr. Pharm. Des. 2015, 21, 4262-4275. [CrossRef] [PubMed]

32. Holten-Andersen, N.; Waite, J.H. Mussel-designed protective coatings for compliant substrates. J. Dent. Res. 2008, 87, 701-709. [CrossRef] [PubMed]

33. Danner, E.W.; Kan, Y.; Hammer, M.U.; Israelachvili, J.N.; Waite, J.H. Adhesion of Mussel Foot Protein Mefp-5 to Mica: An Underwater Superglue. Biochemistry 2012, 51, 6511-6518. [CrossRef]

34. Fan, C.; Fu, J.; Zhu, W.; Wang, D.-A. A mussel-inspired double-crosslinked tissue adhesive intended for internal medical use. Acta Biomater. 2016, 33, 51-63. [CrossRef] [PubMed]

35. Zhang, A.; Neumeyer, J.L.; Baldessarini, R.J. Recent Progress in Development of Dopamine Receptor Subtype-Selective Agents: Potential Therapeutics for Neurological and Psychiatric Disorders. Chem. Rev. 2007, 107, 274-302. [CrossRef]

36. Lee, H.; Dellatore, S.M.; Miller, W.M.; Messersmith, P.B. Mussel-Inspired Surface Chemistry for Multifunctional Coatings. Science 2007, 318, 426-430. [CrossRef] 
37. Xu, J.-g.; Qiu, Z.; Zhao, X.; Zhong, H.; Huang, W. Study of 1-Octyl-3-methylimidazolium bromide for inhibiting shale hydration and dispersion. J. Pet. Sci. Eng. 2019, 177, 208-214. [CrossRef]

38. Yang, L.; Jiang, G.; Shi, Y.; Yang, X. Application of Ionic Liquid and Polymeric Ionic Liquid as Shale Hydration Inhibitors. Energy Fuels 2017, 31, 4308-4317. [CrossRef]

39. Gou, S.; Yin, T.; Xia, Q.; Guo, Q. Biodegradable polyethylene glycol-based ionic liquids for effective inhibition of shale hydration. RSC Adv. 2015, 5, 32064-32071. [CrossRef]

40. Balaban, R.d.C.; Vidal, E.L.F.; Borges, M.R. Design of experiments to evaluate clay swelling inhibition by different combinations of organic compounds and inorganic salts for application in water base drilling fluids. Appl. Clay Sci. 2015, 105-106, 124-130. [CrossRef]

41. Jiang, G.; Zhang, X.; Dong, T.; Xuan, Y.; Wang, L.; Jiang, Q. A new inhibitor of P(AM-DMDAAC)/PVA intermacromolecular complex for shale in drilling fluids. J. Appl. Polym. Sci. 2018, 135, 45584. [CrossRef]

42. Zhong, H.; Qiu, Z.; Sun, D.; Zhang, D.; Huang, W. Inhibitive properties comparison of different polyetheramines in water-based drilling fluid. J. Nat. Gas Sci. Eng. 2015, 26, 99-107. [CrossRef]

43. Xu, J.-G.; Qiu, Z.; Zhao, X.; Mou, T.; Zhong, H.; Huang, W. A polymer microsphere emulsion as a high-performance shale stabilizer for water-based drilling fluids. RSC Adv. 2018, 8, 20852-20861. [CrossRef]

44. Teixeira, G.T.; Lomba, R.F.T.; Francisco, A.D.d.S.; da Silva, J.F.C.; Nascimento, R.S.V. Hyperbranched Polyglycerols, Obtained from Environmentally Benign Monomer, as Reactive Clays Inhibitors for Water-Based Drilling Fluids. J. Appl. Polym. Sci. 2014, 131, 40384.

45. Saffari, H.; Soltani, R.; Alaei, M.; Soleymani, M. Tribological properties of water-based drilling fluids with borate nanoparticles as lubricant additives. J. Pet. Sci. Eng. 2018, 171, 253-259. [CrossRef]

46. Lan, P.; Iaccino, L.L.; Bao, X.; Polycarpou, A.A. The effect of lubricant additives on the tribological performance of oil and gas drilling applications up to $200^{\circ} \mathrm{C}$. Tribol. Int. 2020, 141, 105896. [CrossRef]

47. Jiang, G.; Ni, X.; Li, W.; Quan, X.; Luo, X. Super-amphiphobic, strong self-cleaning and high-efficiency water-based drilling fluids. Pet. Explor. Dev. 2020, 47, 421-429. [CrossRef]

48. Nunes, D.G.; da Silva, A.d.P.M.; Cajaiba, J.; Pérez-Gramatges, A.; Lachter, E.R.; Nascimento, R.S.V. Influence of Glycerides-Xanthan Gum Synergy on Their Performance as Lubricants for Water-Based Drilling Fluids. J. Appl. Polym. Sci. 2014, 131, 41085.

49. Dong, X.; Wang, L.; Yang, X.; Lin, Y.; Xue, Y. Effect of ester based lubricant SMJH-1 on the lubricity properties of water based drilling fluid. J. Pet. Sci. Eng. 2015, 135, 161-167. [CrossRef]

50. Liu, X.; Gao, L.; Wang, Q.; Gu, X.; Du, W.; Zhang, J.; Gang, C. Evaluation and application of poly(ethylene glycol) as lubricant in water-based drilling fluid for horizontal well in Sulige Gas Field. Polym. Int. 2020. [CrossRef]

51. Aftab, A.; Ali, M.; Sahito, M.F.; Mohanty, U.S.; Jha, N.K.; Akhondzadeh, H.; Azhar, M.R.; Ismail, A.R.; Keshavarz, A.; Iglauer, S. Environmental Friendliness and High Performance of Multifunctional Tween 80/ZnO-Nanoparticles-Added Water-Based Drilling Fluid: An Experimental Approach. ACS Sustain. Chem. Eng. 2020, 8, 11224-11243. [CrossRef]

52. Yang, X.; Shang, Z.; Liu, H.; Cai, J.; Jiang, G. Environmental-friendly salt water mud with nano-SiO ${ }_{2}$ in horizontal drilling for shale gas. J. Pet. Sci. Eng. 2017, 156, 408-418. [CrossRef]

53. Zhao, X.; Qiu, Z.; Wang, M.; Huang, W.; Zhang, S. Performance Evaluation of a Highly Inhibitive Water-Based Drilling Fluid for Ultralow Temperature Wells. J. Energy Resour. Technol. 2018, 140, 57. [CrossRef]

54. Zhao, X.; Qiu, Z.; Zhang, Y.; Zhong, H.; Huang, W.; Tang, Z. Zwitterionic Polymer P(AM-DMC-AMPS) as a Low-Molecular-Weight Encapsulator in Deepwater Drilling Fluid. Appl. Sci. 2017, 7, 594. [CrossRef]

55. Jiang, G.C.; Dong, T.F.; Zhang, X.M.; Li, Y.L.; Zhao, L.; Liu, P. Study and application of a new high performance water base drilling fluid XZ. Drill. Fluid Complet. Fluid 2018, 35, 49-55.

(C) 2020 by the authors. Licensee MDPI, Basel, Switzerland. This article is an open access article distributed under the terms and conditions of the Creative Commons Attribution (CC BY) license (http://creativecommons.org/licenses/by/4.0/). 